\title{
Thermal and Ash Characterization of Indonesian Bamboo and Its Potential for Solid Fuel and Waste Valorization
}

\author{
Aprilina Purbasaria,b, Tjokorde Walmiki Samadhia ${ }^{*}$ and Yazid Bindara \\ ${ }^{a}$ Chemical Engineering Program, Faculty of Industrial Technology, Bandung Institute of Technology, INDONESIA \\ ${ }^{b}$ Department of Chemical Engineering, Faculty of Engineering, Diponegoro University, INDONESIA
}

\begin{abstract}
Bamboo has been widely used in Indonesia for construction, handicrafts, furniture and other uses. However, the use of bamboo as a biomass for renewable energy source has not been extensively explored. This paper describes the thermal and ash characterization of three bamboo species found in Indonesia, i.e. Gigantochloa apus, Gigantochloa levis and Gigantochloa atroviolacea. Characterization of bamboo properties as a solid fuel includes proximate and ultimate analyses, calorific value measurement and thermogravimetric analysis. Ash characterization includes oxide composition analysis and phase analysis by XRay diffraction. The selected bamboo species have calorific value comparable with wood with low nitrogen and sulphur contents, indicating that they can be used as renewable energy sources. Bamboo ash contains high silicon so that bamboo ash has potential to be used further as building materials or engineering purposes. Ash composition analysis also indicates high alkali that can cause ash sintering and slag formation in combustion process. This implies that the combustion of bamboo requires the use of additives to reduce the risk of ash sintering and slag formation.
\end{abstract}

Keywords: ash, bamboo, combustion, Gigantochloa apus, Gigantochloa atroviolacea, Gigantochloa levis

Article History: Received May 15, 2016; Received in revised form July 2nd, 2016; Accepted July 14 ${ }^{\text {th }}$, 2016; Available online

How to Cite This Article: Purbasari, A., Samadhi, T.W. \& Bindar, Y. (2016) Thermal and Ash Characterization of Indonesian Bamboo and its Potential for Solid Fuel and Waste Valorization. Int. Journal of Renewable Energy Development, 5(2), 95-100.

http://dx.doi.org/10.14710/ijred.5.2.96-100

\section{Introduction}

The use of biomass as a renewable energy source has increased in line with the limited resources of fossil energy. Although biomass has lower calorific value than coal, oil, or natural gas, the use of biomass as an energy source is more environmentally friendly because produced $\mathrm{CO}_{2}$ gas will be used for growth of biomass so it does not contribute to the greenhouse effect (Demirbas 2005). Biomass can be divided into four types, namely woody plants, grass plants, aquatic plants, and manures (McKendry 2002a). Utilization of biomass into energy can through thermo-chemical process (combustion, gasification, pyrolysis) and biochemical process (fermentation, anaerobic digestion, mechanical extraction) (McKendry 2002b). Combustion process is the simplest way to utilize biomass as energy source.

Bamboo is one of biomass that can be used as an energy source because bamboo has calorific value almost equivalent to wood (Engler et al. 2012). Bamboo is a grass plant species included in the subfamily Bambusoideae and family Andropogoneae/Poaceae and has 1250 species. Bamboo is found in tropical and subtropical regions slightly in the lowlands to the highlands (4000 $\mathrm{m}$ above sea level). Bamboo plant height varies from the shortest of about $10 \mathrm{~cm}$ to $40 \mathrm{~m}$ (Scurlock et al. 2000). Bamboo has fast growth rate because bamboo can be harvested after 3-4 years (Kleinhenz \& Midmore 2001). In Indonesia there are more than 35 species of bamboo. Most of the bamboo plants in Indonesia are sympodial, namely rods tend to get together in clumps and reproduce by rhizomes.

\footnotetext{
* Corresponding Author: +62-22-2500989

Email: twsamadhi@che.itb.ac.id
} 
Citation: Purbasari, A., Samadhi, T.W. \& Bindar, Y. (2016) Thermal and Ash Characterization of Indonesian Bamboo and its Potential for Solid Fuel and Waste Valorization. Int. Journal of Renewable Energy Development, 5(2), 95-100, doi : 10.14710/ijred.5.2.95-100

$\mathrm{P}$ a g e $\mid 96$

Bamboo has been used as construction materials, handicrafts and furniture, pulp and paper industry, as well as musical instruments (Yudodibroto 1987).

To take advantage of bamboo as energy source by combustion process, it is necessary to understand the thermal and ash characteristics of bamboo. In general, high alkaline content in biomass ash can cause ash sintering and slag formation in the combustion process so that it needs to be added additives such as dolomite, kaolin, and limestone which can increase melting point of biomass ash (Llorente et al. 2008). This research studies the thermal and ash characteristics of three bamboo species, i.e. Gigantochloa apus, Gigantochloa levis and Gigantochloa atroviolacea. Combustion residues of bamboo by single combustion and cocombustion with kaolin as additive are also studied.

\section{Materials and Methods}

\subsection{Materials}

Three bamboo species, i.e. G. apus, G. levis and $G$. atroviolacea were obtained from Central Java, Indonesia. Bamboo was dried under the sun for 1 day before characterized and combusted.

Kaolin powder originated from Bangka Belitung, Indonesia. The major oxides in kaolin were $\mathrm{SiO}_{2}$ (53.9\%), $\quad \mathrm{Al}_{2} \mathrm{O}_{3} \quad(42.43 \%), \quad \mathrm{Fe}_{2} \mathrm{O}_{3} \quad(1.17 \%)$ and $\mathrm{K}_{2} \mathrm{O}$ $(1.12 \%)$.

\subsection{Thermal characterization}

Fuel characterization of bamboo included proximate analysis and ultimate analysis, as well as calorific value analysis. Proximate analysis was carried out by ASTM D3172, ultimate analysis by ASTM D3176 and gross calorific value analysis by ASTM D5865.

Combustion characterization of bamboo used Thermal Gravimetric Analyzer (TGA) instrument, namely LINSEIS STA Platinum Series. Sample testing was conducted at room temperature up to $900{ }^{\circ} \mathrm{C}$ with a heating rate of $10{ }^{\circ} \mathrm{C} / \mathrm{min}$ under air atmosphere.

\subsection{Combustion process}

Combustion process of bamboo and bamboo-kaolin mixture were carried out in a fixed bed furnace with capacity of $200 \mathrm{~g}$. Bamboo was cut to size of $0.5 \times 0.5 \times 2$ $\mathrm{cm}$. Combustion of bamboo-kaolin mixture used mass ratio of bamboo:kaolin $=95: 5$. Combustion of bambookaolin mixture was also carried out in an electric furnace at temperature of $500{ }^{\circ} \mathrm{C}$ for an hour to ensure that bamboo had become entirely ash.

\subsection{Ash characterization}

Chemical characterization of bamboo ash involved oxide composition analysis $\left(\mathrm{SiO}_{2}, \mathrm{Al}_{2} \mathrm{O}_{3}, \mathrm{Fe}_{2} \mathrm{O}_{3}, \mathrm{CaO}\right.$, $\mathrm{MgO}, \mathrm{K}_{2} \mathrm{O}, \mathrm{Na}_{2} \mathrm{O}, \mathrm{MnO}, \mathrm{TiO}_{2}, \mathrm{P}_{2} \mathrm{O}_{5}, \mathrm{SO}_{3}$ ). Analysis of $\mathrm{SiO}_{2}$,
$\mathrm{Al}_{2} \mathrm{O}_{3}, \mathrm{Fe}_{2} \mathrm{O}_{3}, \mathrm{CaO}, \mathrm{MgO}, \mathrm{K}_{2} \mathrm{O}, \mathrm{Na}_{2} \mathrm{O}$ and $\mathrm{TiO}_{2}$ used SNI 133608-1994 method; MnO used Atomic Absorption Spectroscopy (AAS) method; $\mathrm{P}_{2} \mathrm{O}_{5}$ used spectrophotometric method and $\mathrm{SO}_{3}$ used gravimetric method.

Combustion residues were analyzed by X-Ray Diffraction (XRD) instrument. XRD analysis was conducted with Bruker D8 Advance at room temperature under following conditions: $40 \mathrm{kV}, 35 \mathrm{~mA}$, $\mathrm{CuK \alpha}$ radiation (wavelength $\lambda_{1}=1.54060 \AA$ and $\lambda_{2}=1.54439 \AA$, intensity ratio $\alpha 1 / \alpha 2=0.5$ ), and range of scanning angle $2 \theta$ from $5^{\circ}$ to $80^{\circ}$ at step size of $0.019^{\circ}$.

\section{Results and Discussion}

\subsection{Thermal characteristics}

\subsubsection{Proximate analysis, ultimate analysis and calorific value analysis}

Proximate analysis results of three bamboo species denote that moisture content, ash content, volatile matter content, and fixed carbon content ranges between 8.13-8.89\%, 2.45-3.29\%, 70.31-72.71\% and $16.07-18.35 \%$ as presented in Table 1. G. atroviolacea has the highest ash content and the lowest calorific value, whereas ash content and calorific value in G. apus and $G$. levis are relatively the same. The calorific values of three bamboo species are not much different from the calorific value of wood, i.e. Leucaena leucocephala and Hibiscus tiliaceus, so that bamboo also has potential to be used as renewable energy source like wood. Moreover moisture content in bamboo is also lower than that in wood. This result indicates that bamboo is easier to be combusted compared to wood (Jenkins et al. 1998).

Tabel 1

Proximate analysis and calorific value of selected bamboo and wood

\begin{tabular}{lccccc}
\hline \multirow{2}{*}{$\begin{array}{l}\text { Name } \\
\text { of species }\end{array}$} & Moisture & Ash & $\begin{array}{c}\text { Volatile } \\
\text { matter }\end{array}$ & $\begin{array}{c}\text { Fixed } \\
\text { carbon }\end{array}$ & $\begin{array}{c}\text { Calorific } \\
\text { value } \\
\text { (cal/g) }\end{array}$ \\
\hline $\begin{array}{l}\text { G. apus } \\
\text { G. levis }\end{array}$ & 8.89 & 2.45 & 70.31 & 18.35 & 4151 \\
$\begin{array}{l}\text { G. atrovio- } \\
\text { lacea }\end{array}$ & 8.76 & 2.46 & 72.71 & 16.07 & 4161 \\
$\begin{array}{l}\text { Leucaena } \\
\text { leucocephala* }\end{array}$ & 10.13 & 3.29 & 71.70 & 16.88 & 4086 \\
$\begin{array}{l}\text { Hibiscus } \\
\text { tiliaceus* }\end{array}$ & 12 & 1.48 & & & 4197 \\
\hline *(Cahyono et al. 2008) & & & & & \\
\end{tabular}

For ultimate analysis as shown in Table 2, the contents of carbon, hydrogen, nitrogen, sulphur and oxygen in G. apus, G. levis and G. atroviolacea bamboo indicate no substantial difference. Nitrogen and sulphur in fuel can generate pollutant gases, i.e. NOx and SOx, in combustion process. Three bamboo species contain nitrogen and sulphur less than $1 \%$, respectively, indicating that bamboo utilization as an energy source 
does not cause major air pollution problems (Jenkins et al. 1998).

Tabel 2

Ultimate analysis of selected bamboo (\%)

\begin{tabular}{|c|c|c|c|c|c|}
\hline $\begin{array}{c}\text { Name } \\
\text { of } \\
\text { species }\end{array}$ & Carbon & Hydrogen & Nitrogen & Sulphur & Oxygen \\
\hline G. apus & 44.29 & 6.16 & 0.53 & 0.10 & 46.47 \\
\hline $\begin{array}{c}G . \text { levis } \\
G .\end{array}$ & 44.65 & 6.35 & 0.48 & 0.09 & 45.97 \\
\hline $\begin{array}{c}\text { atrovio- } \\
\text { lacea }\end{array}$ & 44.11 & 6.26 & 0.47 & 0.07 & 45.80 \\
\hline
\end{tabular}

\subsubsection{Thermogravimetric analysis}

Combustion characteristics of bamboo with thermogravimetric analysis exhibits that three bamboo species experienced four stages of thermal decomposition as shown in Fig. 1, i.e. temperature below $200{ }^{\circ} \mathrm{C}$, temperature of $200-340{ }^{\circ} \mathrm{C}$, temperature of $340-500{ }^{\circ} \mathrm{C}$, and temperature of $500-900{ }^{\circ} \mathrm{C}$.

Phenomenon of bamboo thermal decomposition can be explained from substances contained in bamboo. Bamboo contains lignin (20-30\%), cellulose (40-50\%), hemicellulose (25-30\%), extractive material, and ash (Scurlock et al. 2000, Kumar \& Chandrashekar 2014) as wood. According to Byrne \& Nagle (1997), wood undergoes pyrolysis for hemicellulose at temperature of 200-260 ${ }^{\circ} \mathrm{C}$, cellulose at temperature of $240-350{ }^{\circ} \mathrm{C}$, and lignin at temperature of $280-500{ }^{\circ} \mathrm{C}$.

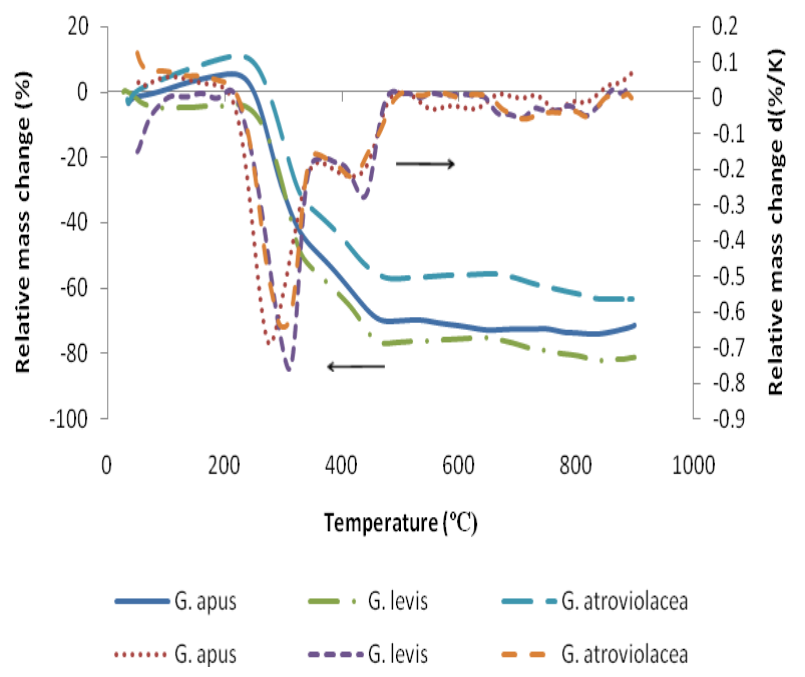

Fig. 1 Combustion profiles of selected bamboo

Bamboo initially undergoes evaporation of water and extractive materials at temperature up to $200^{\circ} \mathrm{C}$. In the next stage, at temperature of $200-340{ }^{\circ} \mathrm{C}$, thermal decomposition of hemicellulose and cellulose are occurred. At this stage the mass loss for G. apus, G. levis, G. atroviolacea are 48.2, 47.9, 44.5\%, respectively with maximum peak temperature are 276, 308, $295{ }^{\circ} \mathrm{C}$, respectively. Furthermore, at temperature of 340-500 ${ }^{\circ} \mathrm{C}$, thermal decomposition of residual cellulose and lignin takes place with mass loss for G. apus, G. levis, $G$. atroviolacea are 26.7, 24.6, 23.3\%, respectively and maximum peak temperature are $434,439,422{ }^{\circ} \mathrm{C}$, respectively. In the fourth stage, at temperature of 500 $900{ }^{\circ} \mathrm{C}$, thermal decomposition of residual lignin is occured and mass loss for $G$. apus, $G$. levis, $G$. atroviolacea are $4.7,7,7.8 \%$, respectively.

\subsection{Ash characteristics}

\subsubsection{Oxide composition analysis}

The oxide compositions of selected bamboo ash are presented in Table 3. G. apus, G. levis and G. atroviolacea has high content of silicon so that bamboo ash has potential to be used further as building materials (brick, cement) or engineering purposes (catalyst, insulator) (Vassilev et al. 2013). Meanwhile potassium is dominant alkali in bamboo ash. The content of alkali in G. apus, G. levis and G. atroviolacea are relatively high as more than $25 \%$ that can lead to the risk of ash sintering and slag formation in combustion process of bamboo (Jenkins et al. 1998).

\subsubsection{X-ray diffraction analysis}

X-ray diffractograms for bamboo (G. apus) ash and kaolin are given on Fig. 2 and Fig. 3, respectively. Bamboo ash contains mineral phases, namely arcanite $\left(\mathrm{K}_{2} \mathrm{SO}_{4}\right)$, sylvite $(\mathrm{KCl})$, and quartz $\left(\mathrm{SiO}_{2}\right)$. This result is in accordance with oxide composition analysis that silicon and potassium are dominant in bamboo. Meanwhile, kaolinite is the dominant mineral phase in kaolin.

Co-combustion residue of bamboo-kaolin mixture denotes mineral phases both in bamboo ash (arcanite, sylvite, and quartz) and in kaolin (kaolinite) from X-ray diffractogram as shown on Fig. 4.

Co-combustion residue of bamboo-kaolin mixture further is burnt in electric furnace at temperature of $500{ }^{\circ} \mathrm{C}$ for an hour. X-ray diffractogram on Fig. 5 shows that there are arcanite, quartz, and kalsilite $\left(\mathrm{KAlSiO}_{4}\right)$ mineral phases.

Kalsilite $\left(\mathrm{KAlSiO}_{4}\right)$ is formed from the reaction between kaolinite $\left(\mathrm{Al}_{2} \mathrm{Si}_{2} \mathrm{O}_{5}(\mathrm{OH})_{4}\right)$ from kaolin with sylvite $(\mathrm{KCl})$ and arcanite $\left(\mathrm{K}_{2} \mathrm{SO}_{4}\right)$ from bamboo according to the following reaction (Konsomboon et al. 2011):

$\mathrm{Al}_{2} \mathrm{Si}_{2} \mathrm{O}_{5}(\mathrm{OH})_{4}+2 \mathrm{KCl} \rightarrow 2 \mathrm{KAlSiO}_{4}+\mathrm{H}_{2} \mathrm{O}+2 \mathrm{HCl}$
$\mathrm{Al}_{2} \mathrm{Si}_{2} \mathrm{O}_{5}(\mathrm{OH})_{4}+\mathrm{K}_{2} \mathrm{SO}_{4} \rightarrow 2 \mathrm{KAlSiO}_{4}+2 \mathrm{H}_{2} \mathrm{O}+\mathrm{SO}_{3}$ 
Citation: Purbasari, A., Samadhi, T.W. \& Bindar, Y. (2016) Thermal and Ash Characterization of Indonesian Bamboo and its Potential for Solid Fuel and Waste Valorization. Int. Journal of Renewable Energy Development, 5(2), 95-100, doi : 10.14710/ijred.5.2.95-100

$\mathrm{P}$ a g e $\mid 98$

Tabel 3

Oxide compositions of selected bamboo ash (\%)

\begin{tabular}{ccccccccccccc}
\hline $\begin{array}{c}\text { Name } \\
\text { of species }\end{array}$ & $\mathbf{S i O}_{2}$ & $\mathbf{A l}_{\mathbf{2}} \mathbf{O}_{3}$ & $\mathbf{F e}_{2} \mathbf{O}_{3}$ & $\mathbf{C a O}$ & $\mathbf{M g O}$ & $\mathbf{K}_{\mathbf{2}} \mathbf{O}$ & $\mathbf{N a}_{2} \mathbf{O}$ & $\mathbf{M n O}$ & $\mathbf{T i O}_{2}$ & $\mathbf{P}_{2} \mathbf{O}_{\mathbf{5}}$ & $\mathbf{S O}_{3}$ & \\
\hline G. apus & 58.6 & 0.73 & 0.51 & 2.68 & 2.82 & 26.43 & 0.51 & 0.048 & 0.90 & 3.37 & 3.40 \\
G. levis & 45.8 & 0.22 & 0.26 & 4.50 & 3.94 & 34.16 & 1.49 & 0.090 & 0.71 & 4.22 & 4.61 \\
G. atroviolacea & 49.5 & 0.20 & 0.24 & 2.88 & 2.15 & 33.46 & 0.85 & 0.051 & 0.86 & 6.24 & 3.57 \\
\hline
\end{tabular}

The reaction indicates that alkali in bamboo ash can be chemically bound by kaolin. Therefore, the addition of kaolin in bamboo combustion process can reduce the risk of sintering and slag formation.

Result of XRD characterization analysis also includes the quantification of proportions of total crystalline and amorphous phases as presented in Table 4. Further combustion of bamboo-kaolin mixture in the furnace at temperature of $500{ }^{\circ} \mathrm{C}$ increases the proportion of the amorphous phase. The combustion residue containing high silica (from bamboo) and alumina (from kaolin) with amorphous structure has possibility to be utilized as pozzolanic material for cement production (Rajamma et al. 2009).

Tabel 4

Material structure based on XRD analysis

\begin{tabular}{lcc}
\hline \multirow{2}{*}{ Material } & \multicolumn{2}{c}{ Structure } \\
\cline { 2 - 3 } & $\begin{array}{l}\text { Crystalline } \\
\text { (\%) }\end{array}$ & $\begin{array}{l}\text { Amorphous } \\
\text { (\%) }\end{array}$ \\
\hline Bamboo (G. apus) ash & 45.4 & 54.6 \\
Kaolin & 78.6 & 21.4 \\
$\begin{array}{l}\text { Combustion residue of bamboo- } \\
\text { kaolin mixture }\end{array}$ & 48.6 & 51.4 \\
$\begin{array}{l}\text { Combustion residue of bamboo- } \\
\text { kaolin mixture at } 500{ }^{\circ} \mathrm{C}\end{array}$ & 43.9 & 56.1 \\
& & \\
\end{tabular}

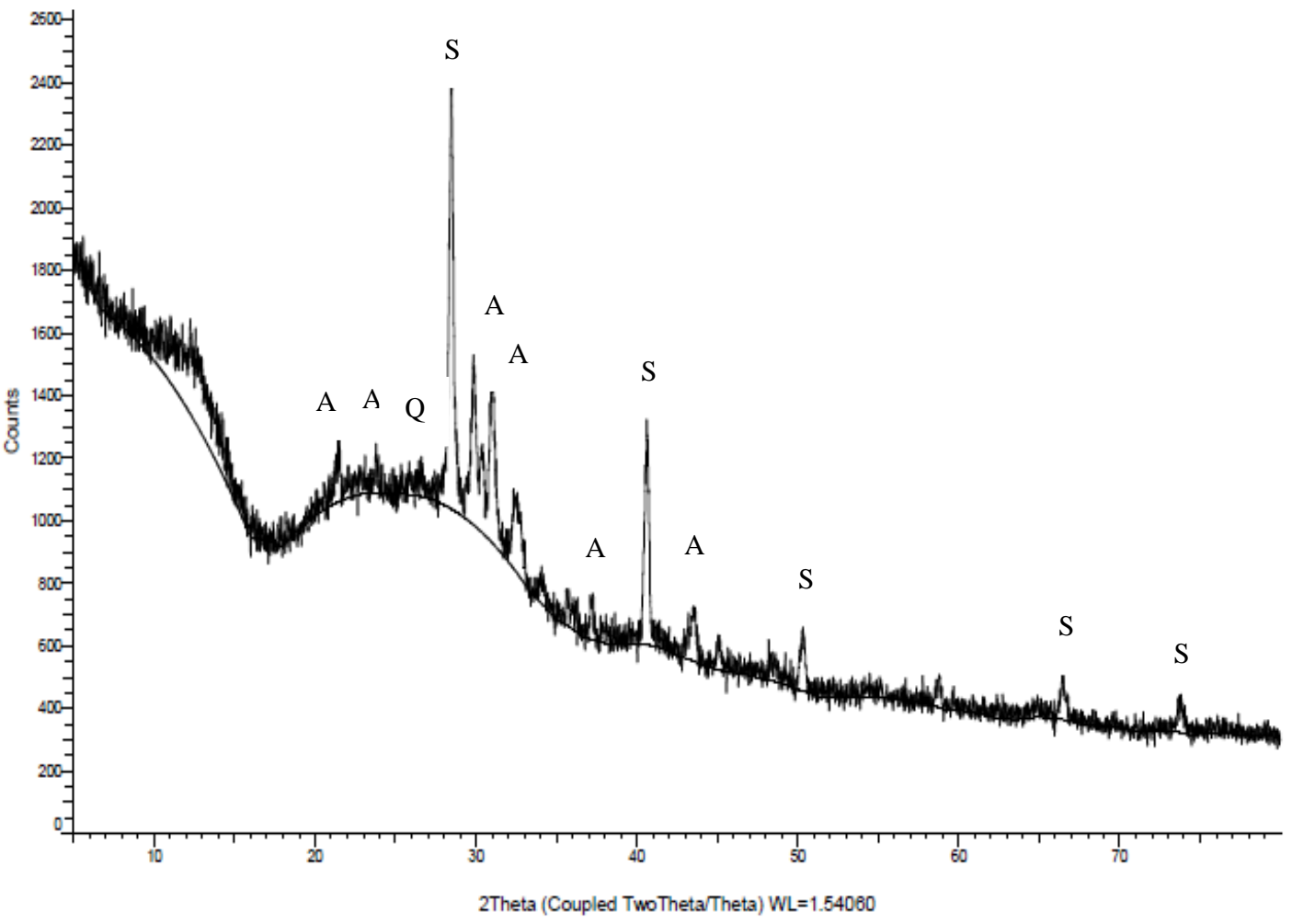

Fig. $2 \mathrm{X}$-ray diffractogram for bamboo (G. apus) ash $\left(\mathrm{A}=\operatorname{arcanite}\left(\mathrm{K}_{2} \mathrm{SO}_{4}\right), \mathrm{S}=\operatorname{sylvite}(\mathrm{KCl}), \mathrm{Q}=\right.$ quartz $\left.\left(\mathrm{SiO}_{2}\right)\right)$ 


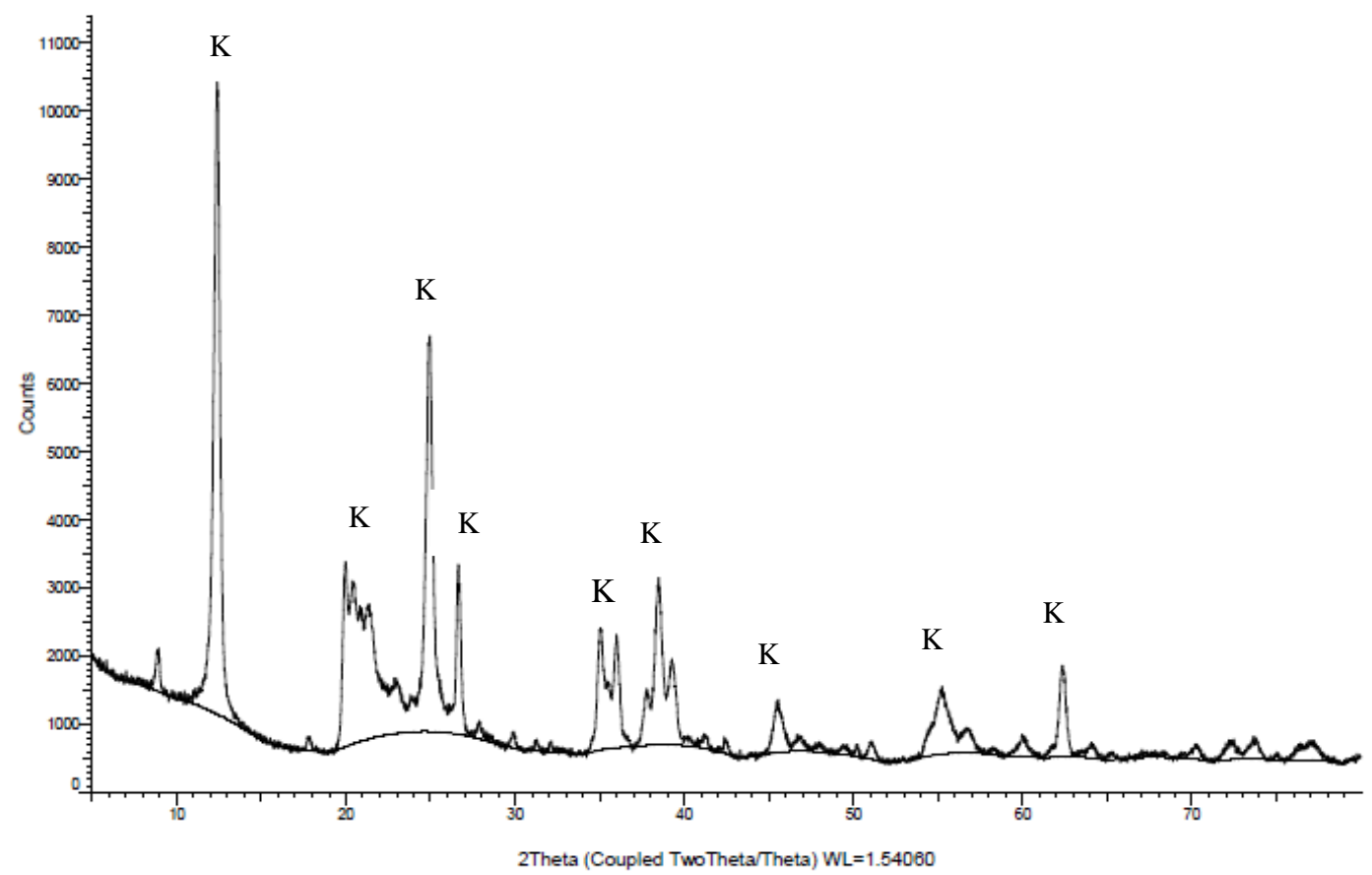

Fig. $3 \mathrm{X}$-ray diffractogram for kaolin $\left(\mathrm{K}=\right.$ kaolinite $\left.\left(\mathrm{Al}_{2} \mathrm{Si}_{2} \mathrm{O}_{5}(\mathrm{OH})_{4}\right)\right)$

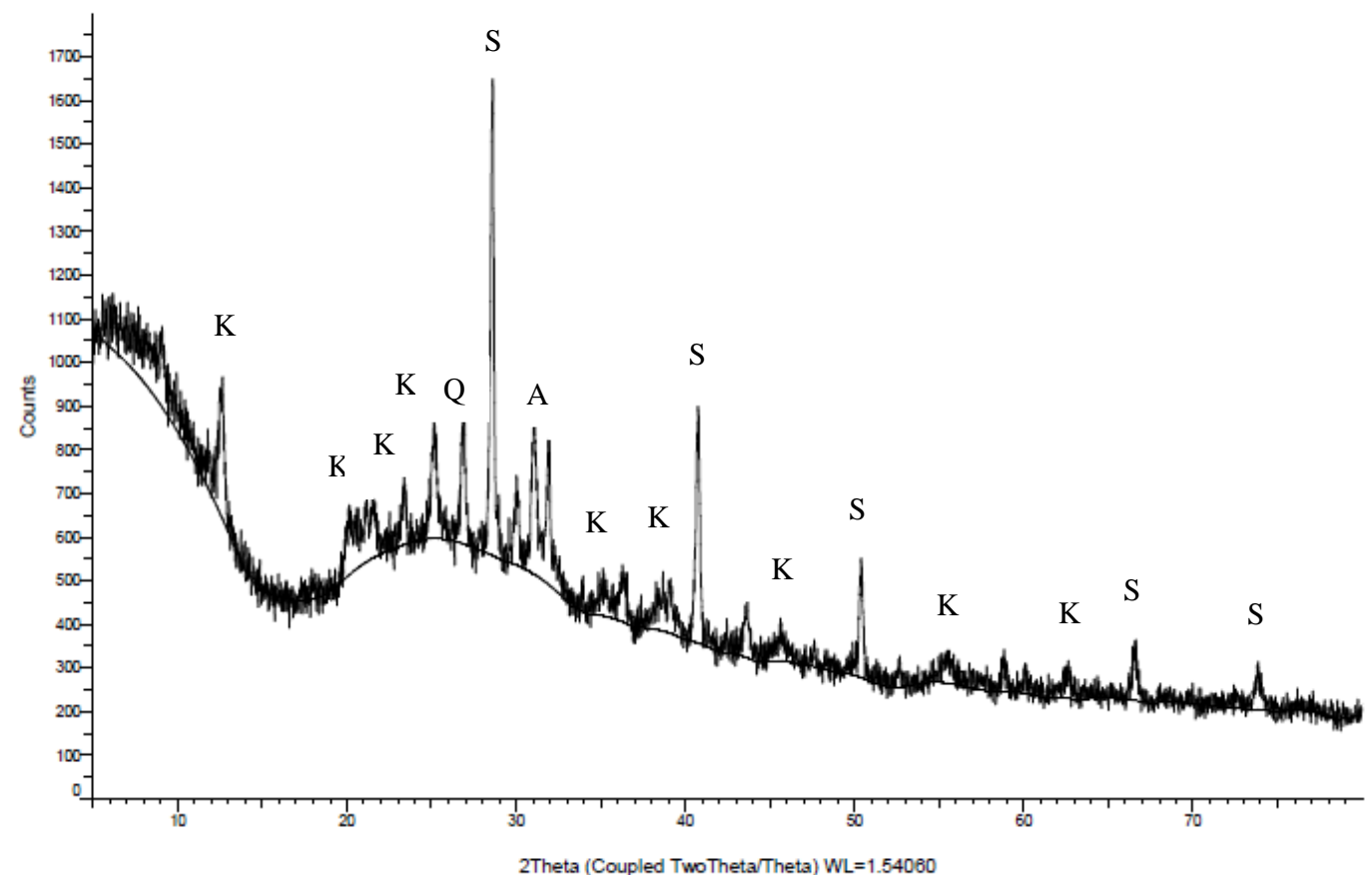

Fig. $4 \mathrm{X}$-ray diffractogram for combustion residue of bamboo-kaolin mixture $\left(\mathrm{A}=\right.$ arcanite $\left(\mathrm{K}_{2} \mathrm{SO}_{4}\right), \mathrm{K}=$ kaolinite $\left(\mathrm{Al}_{2} \mathrm{Si}_{2} \mathrm{O}_{5}(\mathrm{OH})_{4}\right), \mathrm{S}=\mathrm{sylvite}(\mathrm{KCl}), \mathrm{Q}$ $=$ quartz $\left.\left(\mathrm{SiO}_{2}\right)\right)$ 


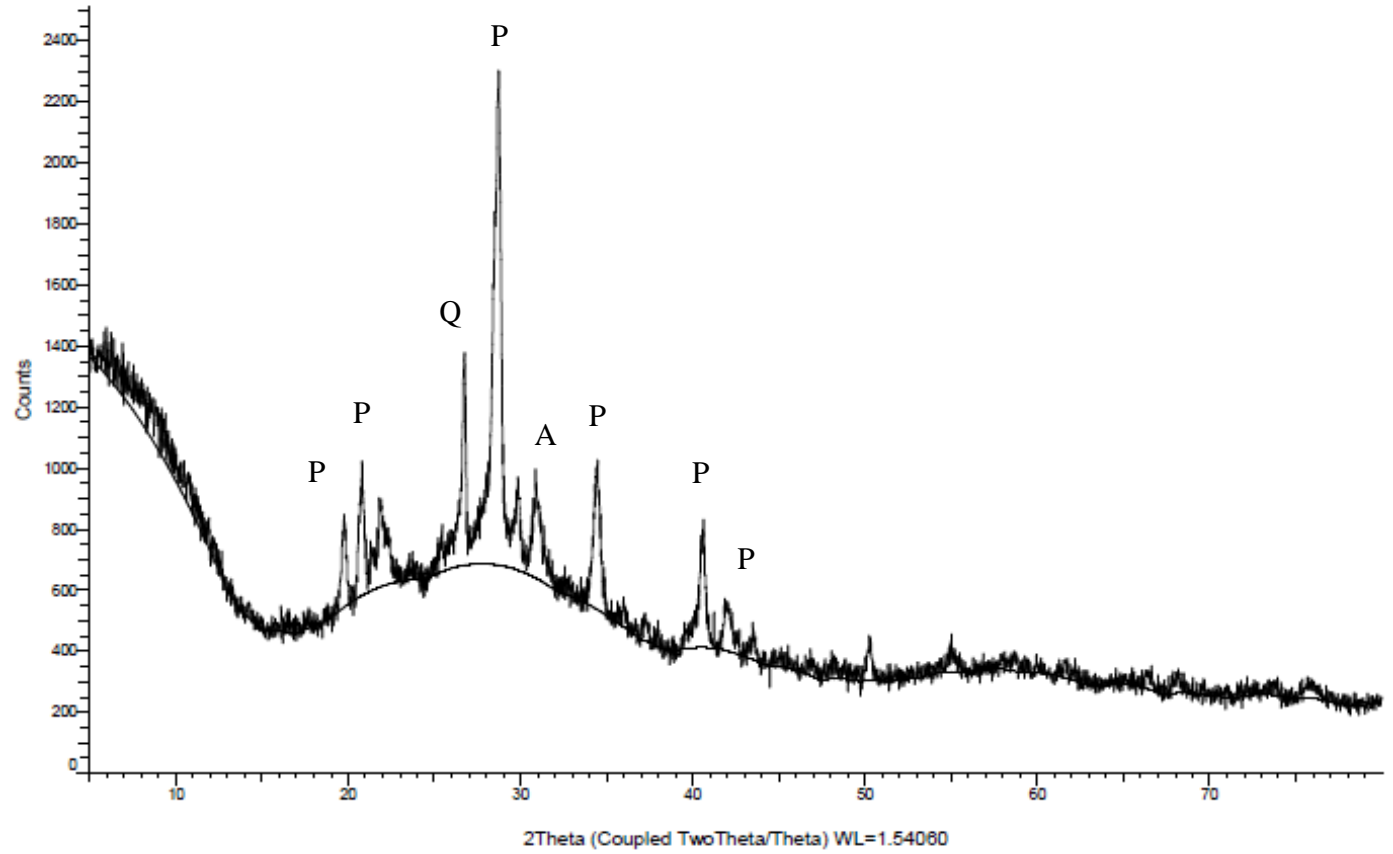

Fig. $5 \mathrm{X}$-ray diffractogram for combustion residue of bamboo-kaolin mixture at $500{ }^{\circ} \mathrm{C}\left(\mathrm{A}=\right.$ arcanite $\left.\left(\mathrm{K}_{2} \mathrm{SO}_{4}\right), \mathrm{P}=\mathrm{kalsilite}_{(\mathrm{KAlSiO}}\right)$, Q $=$ quartz $\left.\left(\mathrm{SiO}_{2}\right)\right)$

\section{Conclusion}

Thermal and ash characterization has been done for three bamboo species, i.e. G. apus, G. levis and $G$. atroviolacea. The selected bamboo can be used as renewable energy source because of their comparable calorific value with wood and low contents of nitrogen and sulphur. Bamboo ash can be utilized as building materials or engineering purposes due to high silicon content. Bamboo ash also contains high alkali that can cause sintering and slag formation in combustion process. The addition of kaolin in the combustion process of bamboo can reduce the risk of sintering and slag formation because it will bind alkali.

\section{References}

Byrne, C.E. \& Nagle, D.C. (1997) Carbonization of Wood for Advanced Materials Applications. Carbon, 35(2), 259-266.

Cahyono, T.D., Coto, Z. \& Febrianto, F. (2008) Thermophisic Aspect of Wood Utilization as Substitution Fuel at Cement Factory. Jurnal Ilmu dan Teknologi Hasil Hutan, 1(1), 45-53.

Demirbas, A. (2005) Potential Applications of Renewable Energy Sources, Biomass Combustion Problems in Boiler Power Systems and Combustion Related Environmental Issues. Progress in Energy and Combustion Science, 31, 171-192.

Engler, B., Schoenherr, S., Zhong, Z. \& Becker, G. (2012) Suitability of Bamboo as An Energy Resource: Analysis of Bamboo Combustion Values Dependent on The Culm's Age. International Journal of Forest Engineering, 23(2), 114-121.

Jenkins, B.M., Baxter, L.L., Miles J.T.R. \& Miles, T.R. (1998) Combustion Properties of Biomass. Fuel Processing Technology, 54, 17-46.
Kleinhenz, V., Midmore, D.J. (2001) Aspects of bamboo agronomy. Advances in Agronomy, 74, 99-145.

Konsomboon, S., Pipatmanomai, S., Madhiyanon, T. \& Tia, S. (2011) Effect of Kaolin Addition on Ash Characteristics of Palm Empty Fruit Bunch (EFB) Upon Combustion. Applied Energy, 88, 298-305.

Kumar, R. \& Chandrashekar, N. (2014) Fuel Properties and Combustion Characteristics of Some Promising Bamboo Species in India. Journal of Forestry Research, 25(2), 471-476.

Llorente, M.J.F., Arocas, P.D., Nebot, L.G. \& Garcia, J.E.C. (2008) The Effect of The Addition of Chemical Materials on The Sintering of Biomass Ash. Fuel, 87(12), 2651-2658.

McKendry, P. (2002a) Energy Production from Biomass (Part 1): Overview of Biomass. Bioresource Technology, 83, 37-46.

McKendry, P. (2002b) Energy Production from Biomass (Part 2): Conversion Technologies. Bioresource Technology, 83, 47-54.

Rajamma, R., Ball, R.J., Tarelho, L.A.C., Allen, G.C., Labrincha, J.A. \& Ferreira, V.M. (2009) Characterisation and use of biomass fly ash in cement-based materials. Journal of Hazardous Materials, 172, 1049-1060.

Scurlock, J.M.O., Dayton, D.C. \& Hames, B. (2000) Bamboo: An Overlooked Biomass Resource? Biomass and Bioenergy, 19, 229244.

Vassilev, S.V., Baxter, D., Andersen, L.K., \& Vassileva, C.G. (2013) An Overview of The Composition and Application of Biomass Ash. Part 2. Potential Utilisation, Technological and Ecological Advantages and Challenges. Fuel, 105, 19-39.

Yudodibroto, H. (1987) Bamboo Research in Indonesia. Proceedings of the International Bamboo Workshop, Hangzhou, R.R.C., Rao, A.N., G. Dhanarajan, G., Sastry, C.B., eds., IDRC, 33-44. 